\title{
SENSONATOR VALENTIENSIS N. G., N. SP. (AMPHIPODA) FROM DIFFERENT BIOTOPES IN SOUTHERN VALENCIA*
}

\author{
by \\ JOS NOTENBOOM \\ Institute of Taxonomic Zoology, University of Amsterdam, P.O. Box 20125, 1000 HC Amsterdam, \\ The Netherlands
}

\begin{abstract}
A new species, Sensonator valentiensis, the only representative of a new subterranean amphipod genus, was discovered in a rather small area in the S.E. part of the province of Valencia. A few specimens have been found in wells, a hyporheic habitat, and a phreatic cave lake.

In general, Sensonator has a rather primitive morphology with remarkable features such as presence of calceoli on the antennae in both sexes, reductions in the mouthparts, and a natatory third uropod. The new genus is very distinct from other stygobiont amphipods, and it cannot even be classified in one of the existing families of Gammaridea, but with some reserve it is placed close to the Gammaroidea and Pardaliscoidea.

$S$. valentiensis was not attracted by baits, but has been seen grasping prey; the animal is observed to be a good swimmer, although it also creeps on muddy substrates. Its favoured biotope is assumed to be large fissures in the saturated zone of the karst; from there it seems to have colonized macroporous alluvia.

Active colonization from the marine environment into the littoral karst during Miocene, or possibly Late Cretaceous, is proposed as evolutionary scenario.
\end{abstract}

\section{RESUMEN}

Una nueva especie, Sensonator valentiensis, el único representante de un nuevo género de anfípodos subterráneos ha sido descubierta en una pequeña área del sudoeste de Valencia. Pocos especímenes fueron encontrados en pozos, en un hábitat hyporreico, y en un lago freático de una cueva.

En general Sensonator tiene una morfología bastante primitiva, algunas de sus características más típicas son: calcéolos a lo largo de las antenas en ambos sexos, reducciones en las partes bucales, y el tercer urópodo natatorio. El género nuevo es muy distinto de otros anfípodos subterráneos, y aunque aún no puede ser clasificado en una de las familias existentes de Gammaridea, es ubicado con algunas reservas, cerca de los Gammaroidea y Pardaliscoidea.

S. valentiensis no fué atraido por cebo, pero ha sido visto capturando presas; se ha observado que el animal es un

* Groundwater crustaceans of Spain, 2. buen nadador, aunque también se arrastra sobre el sustrato fangoso. Se asume que el biotopo más favorable son las hendiduras grandes en la zona saturada del karst; desde allí coloniza los sedimentos alluviales macroporales.

Se propone un escenario evolutivo en el cual tuvo lugar una activa colonización desde el ambiente marino hacia karst litoral durante el Mioceno, ó quizás el Cretácico Superior.

\section{INTRODUCTION}

In the course of a study on the zoogeography of stygobiont malacostracans of the Iberian Peninsula a new monotypic amphipod genus, called Sensonator, has been discovered in southern Valencia (fig. 1). During a fieldwork period in 1983-1984 (Notenboom \& Meijers, 1985), few, mainly small-sized specimens of Sensonator were found in three isolated localities. In order to obtain more material for an adequate taxonomic study of this new taxon we returned to its distribution area in the summer of 1985 to collect this rare species again. At this time we succeeded in catching a number of large individuals in one of the previous localities, but also a new biotope was discovered, a phreatic lake in a cave. The occurrence of Sensonator in the saturated zone of the karst has stimulated formulation of a hypothesis about its origin.

Many taxa of hypogean amphipods are considered to have evolved from a benthic littoral fauna, particularly those groups for which a regression model evolution is assumed, as pointed out for hadziid Amphipoda (Stock, 1977) and Pseudoniphargus (Stock, 1980). According to this scenario, populations which inhabited littoral or shallow seas "stranded" during marine regressions and adapted to continental subterranean waters. Supposedly, the 


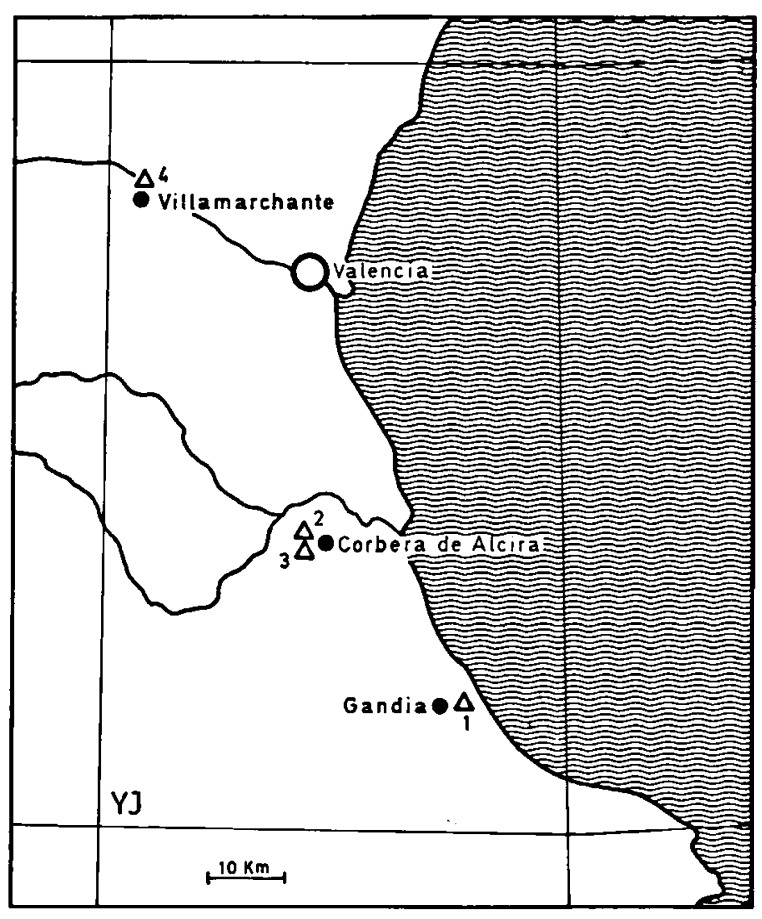

Fig. 1. Map of the southern part of the province of Valencia with universal transverse mercator (UTM) grid; triangles indicate localities with Sensonator valentiensis $\mathbf{n}$. sp.: 1, well at Guardamar; 2, well of San Bernardo; 3, Cueva Blanca; 4, river Turia.

ancestors of these regression elements are so to speak preadapted by a fossorial or interstitial mode of life. In this context Sensonator is an interesting case, because it is argued in the present paper that its ancestor penetrated into the continental groundwaters from a pelagic and not from a benthic marine group.

\section{TAXONOMIC PART}

\section{Sensonator n. g.}

Diagnosis. - Slender, blind and unpigmented. Head small, rostrum lacking. Interantennal lobe and inferior antennal sinus well developed, very clearly demarcated.

First antenna shorter than second; peduncle short, segments 1 and 2 of equal length, segment 3 short; flagellum segments bearing both aesthetascs and calceoli, accessory flagellum 3to 5-segmented. Second antenna with calceoli on last peduncular segment and flagellum. Calceoli of the gammarid type.

Upper lip entire. Mandible: large incisor without teeth; molar reduced. Lacinia mobilis asymmetrical: left a large broad tooth and right a small conical tooth. Palp with long and rather wide second segment, third segment with many rows of A-setae, B- and C-setae lacking. First maxilla with small inner lobe with one distal seta, outer lobe with 9 distal spines, palp 2segmented. Second maxilla with broad and apically densely armed plates, without oblique row of setae on inner plate. Maxillipedal inner and outer lobes small, palp 4-segmented. Lower lip without inner lobes.

Gnathopods strong, first smaller than second, palmar margin armed with simple setae on both margins, palmar angle with a group of spines. Coxal plates small, overlapping, coxae 1 to 4 subquadrate, coxae 5 to 7 wider than long, coxae 5 and 6 anterolobate, coxa 7 nonlobate. Sternal gills lacking, coxal gills on pereiopods 2 to 6 with demarcated stalk. Oostegites linear. Pleopods with two well-developed rami.

Urosome with several dorsal and dorsolateral spines. First uropod longer than second. Third uropod with subfoliaceous rami of equal length; exopodite 2-segmented, distal segment very small. Telson lobes separated to base.

No secondary sexual differences.

Type-species. - S. valentiensis n. sp.

Etymology. - Sensonator is a contraction of the latin words sensus (= sense), alluding to the presence of many calceoli, and natare (= to swim). The type-species is named after the area in which it has been found, the Spanish province of Valencia.

Sensonator valentiensis $n$. sp.

(Figs. 2-6)

Material examined. - Prov. Valencia, Gandia, large well at Guardamar, partly covered by construction with motor pump, along the road Daimúz-Miramar, 500 $m$ from Daimúz ( $=2.5 \mathrm{~km}$ E. of Gandia), UTM coordinates: YJ469168, alt. 10 m; 8 Feb. 1984 (sta. 84-2/34), 1 \&, $20^{\circ} 0^{\circ}$ and 1 juv., paratypes (ZMA coll. no. Amph. 107.945); temp. $17.9^{\circ} \mathrm{C}$, conductivity $1263 \mu \mathrm{S} / \mathrm{cm}, \mathrm{pH}$ 7.11 , oxygen $6.8 \mathrm{mg} / \mathrm{l}$, chlorinity $68 \mathrm{mg} / \mathrm{l}$. Accompanying 
fauna: Haploginglymus, Gastropoda (Hydrobioidea and Basommatophora), and Oligochaeta.

Prov. Valencia, Corbera de Alcira, large, open well partly covered by construction with motor pump at the abandoned garden of San Bernardo (fig. 7B), about $1 \mathrm{~km}$ N.W. of Corbera de Alcira, UTM coordinates: YJ277385, alt. $10 \mathrm{~m}$; 5 March 1984 (sta. 84-3/17), 1 \& paratype (ZMA coll. no. Amph. 107.947); temp. $16.7^{\circ} \mathrm{C}$, conductivity $1114 \mu \mathrm{S} / \mathrm{cm}, \mathrm{pH} 7.38$, chlorinity $82 \mathrm{mg} / \mathrm{l}$. Same locality, 14 May 1984 (sta. 84-5/57), 2 juvs., paratypes (ZMA coll. no. Amph. 107.949); temp. $17.8^{\circ} \mathrm{C}$, conductivity $1109 \mu \mathrm{S} / \mathrm{cm}, \mathrm{pH} 7.28$, chlorinity 88 mg/l. Same locality: 25 July 1985 (sta. 85-7/32), 1 \& holotype, $1 \circ^{\circ}, 6 \% \propto$ and 3 juvs., paratypes (ZMA coll. no. Amph. 107.944); temp. $19.5^{\circ} \mathrm{C}$. Accompanying fauna in this well: Salentinella, Microparasellidae, Harpacticoida, Cyclopoida, Ostracoda, Gastropoda (Basommatophora), Turbellaria, Culicidae, Oligochaeta and Nematoda.

Prov. Valencia, Corbera de Alcira, phreatic lake in Cueva Blanca, entrance of this cave situated in a quarry, $2 \mathrm{~km} \mathrm{~W}$. of Corbera de Alcira (this station is located 500 m S. of previous well), UTM coordinates YJ276381, alt. $40 \mathrm{~m}$; 25 July 1985 (sta. 85-7/31), 3 \& paratypes (ZMA coll. no. Amph. 107.946; 1 \& deposited in National Museum of Natural Sciences of Canada), together with Typhlocirolana. A chemical/physical analysis of this cave water was done on $5 \mathrm{March} 1984$, however at that time no fauna was collected, temp. $15.2^{\circ} \mathrm{C}$, conductivity 390 $\mu \mathrm{S} / \mathrm{cm}$, chlorinity $14 \mathrm{mg} / \mathrm{l}$.

Prov. Valencia, Bou-Rouch probing of river Turia, near bridge between Villamarchante and Liria (fig. 7A), UTM coordinates: YJ045840, alt. $95 \mathrm{~m} ; 6$ March 1984 (sta. 84-3/23), 2 small ơ and 2 juvs., paratypes (ZMA coll. no. Amph. 107.948); temp. $14.8^{\circ} \mathrm{C}$, conductivity $1298 \mu \mathrm{S} / \mathrm{cm}, \mathrm{pH} 7.66$, chlorinity $142 \mathrm{mg} / \mathrm{l}$. Accompanying fauna: Haploginglymus, Salentinella, Bogidiella, juvenile oculate amphipods, Proasellus, Typhlocirolana, Cyclopoida, Ostracoda, Bivalvia (Sphaeriidae), insect larvae and Oligochaeta.

Description. - Largest female $13.0 \mathrm{~mm}$ (with nonsetose oostegites) from Cueva Blanca, female (with setose oostegites) of $10.5 \mathrm{~mm}$ length from Gandia (fig. 2), no ovigerous females present in the material; largest male 6.5 mm from Gandia.

First antenna (fig. 5a): peduncle short, extending to half the length of peduncular segment 4 of $A 2$, peduncular segments 1 and 2 of equal length, segment 3 very short, all segments

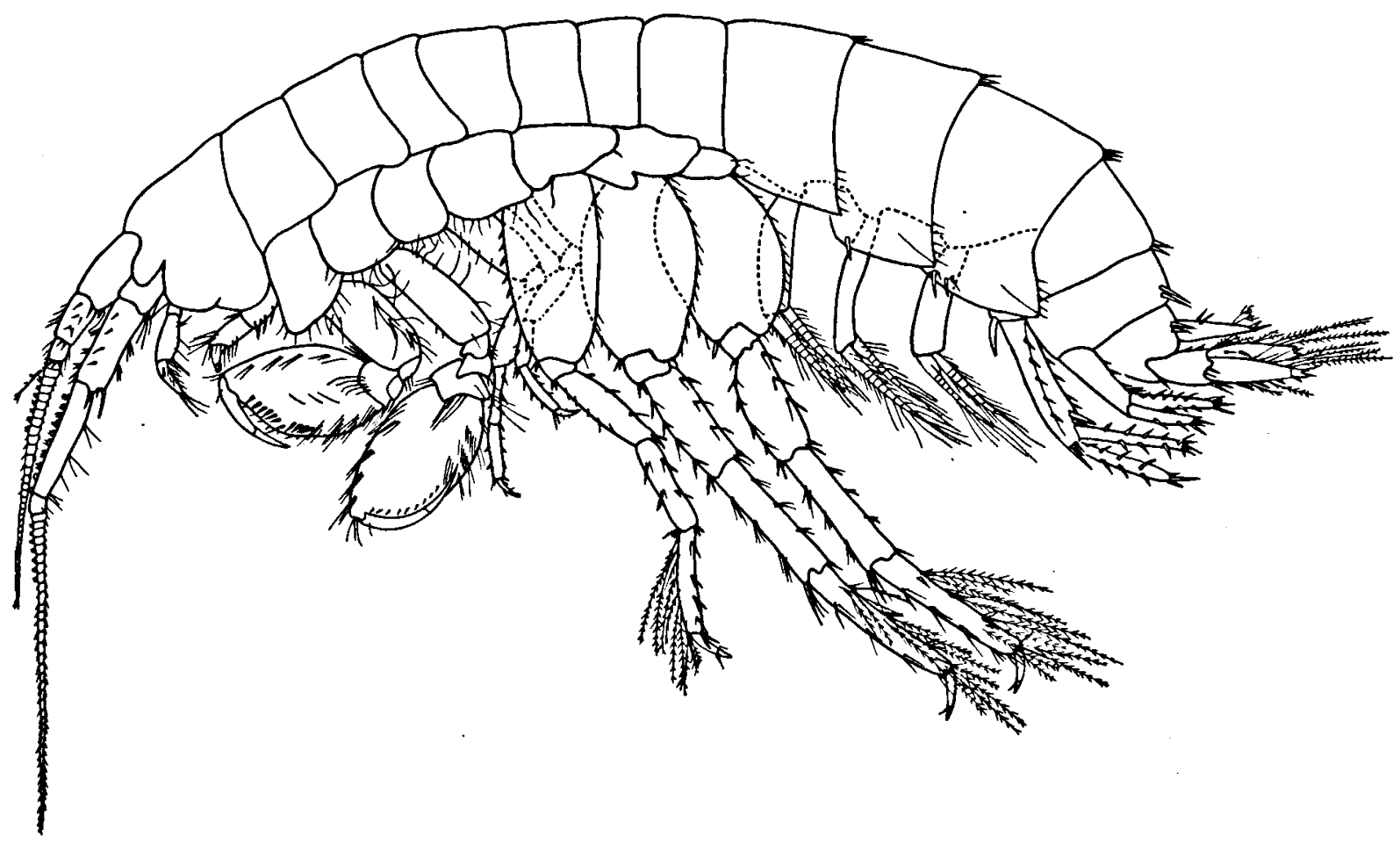

Fig. 2. Sensonator valentiensis n. sp., female of $10.5 \mathrm{~mm}$. 
armed posteriorly with few small spines, setae and sensory setules; flagellum with up to 37 segments; proximal segments with both aesthetascs and calceoli, distal segments with aesthetascs only; aesthetascs cudgel-shaped (fig. $6 c$ ) and half the length of the corresponding segments, in the males most flagellar segments possess 2 aesthetascs, females mostly only one; accessory flagellum (figs. 5b, c) 3 - to 5segmented, the first three segments of equal length, the fourth segment about 1.5 times as long as segment 3 , fifth segment minute, distal parts of all segments with few setae, segment 4 also bearing a short spine and plumose setae.

Second antenna (fig. 5d) about half as long as the body; antennal gland cone small, peduncle segments 4 and 5 of equal length, armed on ventral margins with long spines and setae; calceoli present on dorsal margin of last peduncular segment and also on proximal flagellum segments; flagellum with up to 42 segments, each segment with group of setae, several of these groups have a thick "seta" wich possibly is a ribbon-shaped aesthetasc.

Upper lip (fig. 3a) with rounded apical margin and small lateral lobes. Mandible (figs. $3 \mathrm{~b}, \mathrm{c}$ ): incisor without teeth, molar reduced (in the right mandible a sclerotized structure is still visible); lacinia mobilis asymmetrical, left a large broad tooth and right a small conical tooth; spine row consisting of few naked spines; palp 3-segmented, first segment short, second segment long and rather wide with few lateral setae and distal row of about 10 serrate setae, third segment (fig. 3d) rather short with about 7 rows of A-setae, B- and C-setae lacking, 19-21 D-setae and 4 E-setae. First maxilla (fig. $3 \mathrm{~g}$ ): small inner lobe with one apical seta, outer lobe with 9 smooth spines, palp 2-segmented, terminal segment (figs. $3 g, h$ ) with apical and subapical spines. Second maxilla (fig. $3 f$ ): endopodite distally armed with about 9 setae, exopodite with about 14 setae and 1 lateral spine. Maxilliped (fig. 3i) with small inner and outer lobes, inner lobe with 4 apical spines, outer lobe with medial and apical spines; palp slender and 4-segmented, segments 2 and 3 robust, segment 2 with setiferous medial margin, segment 3 with many apical setae, segment 4 claw-shaped, smaller and shorter than the third. Lower lip (fig. 3e) without inner lobes and with bilobate outer lobe.

Gnathopods very strong, first gnathopod (figs. $3 \mathrm{j}, \mathrm{k}$ ) smaller than second. Coxal plate of first gnathopod small, subquadrate, lower margin armed with 8 rather long setules; basis strong and wide with long setae on the posterior margin; carpus small, with posterodistal projection, bearing a group of setae; propodus globular, posterior margin with up to 8 rows of setae, 3 or 4 palmar angle spines, palmar margin concave bearing many simple setae on both sides and some longer midpalmar setae, a serrate seta near implantation of slender dactylus, unguis very slender.

Second gnathopod (figs. 3-1, m) also with small, subquadrate coxal plate, lower margin with 8 setae; basis wide with long setae on the posterior margin; carpus small, posterodistal projection bearing 3-4 rows of setae; propodus ovoid, posterior margin short with 5 groups of setae, 4 long palmar angle spines, palma oblique, concave and armed like first gnathopod, dactylus and unguis very slender.

Third pereiopod (fig. 4a) larger than fourth (fig. 4b); both with small subquadrate coxae; basis long, posterior margin with long setae, anterior margin with spinules; distal segments armed with short spines; dactylus and claw short.

Coxal gills showing demarcated stalk which is about twice longer than wide. Oostegites linear, with many setae.

Fifth pereiopod (fig. 4c) shorter than equalsized P6 and P7 (figs. 4d and 4e); coxal plates small, wider than long, plates 5 and 6 anterolobate; basis increasing in width from P5 to P7, posterior lobe wide; distal segments armed with short spines in $\mathrm{P} 5$, longer spines in P7, anterior margin of propodus bearing many long plumose setae, dactylus slender with a short unguis. Basis of P5 (fig. 4c) more or less rectangular with slightly overhanging posterodistal corner, anteriorly with about 9 spines, and posteriorly with about 9 setules. Basis of P6 (fig. 4d) ovate, posterodistal angle 


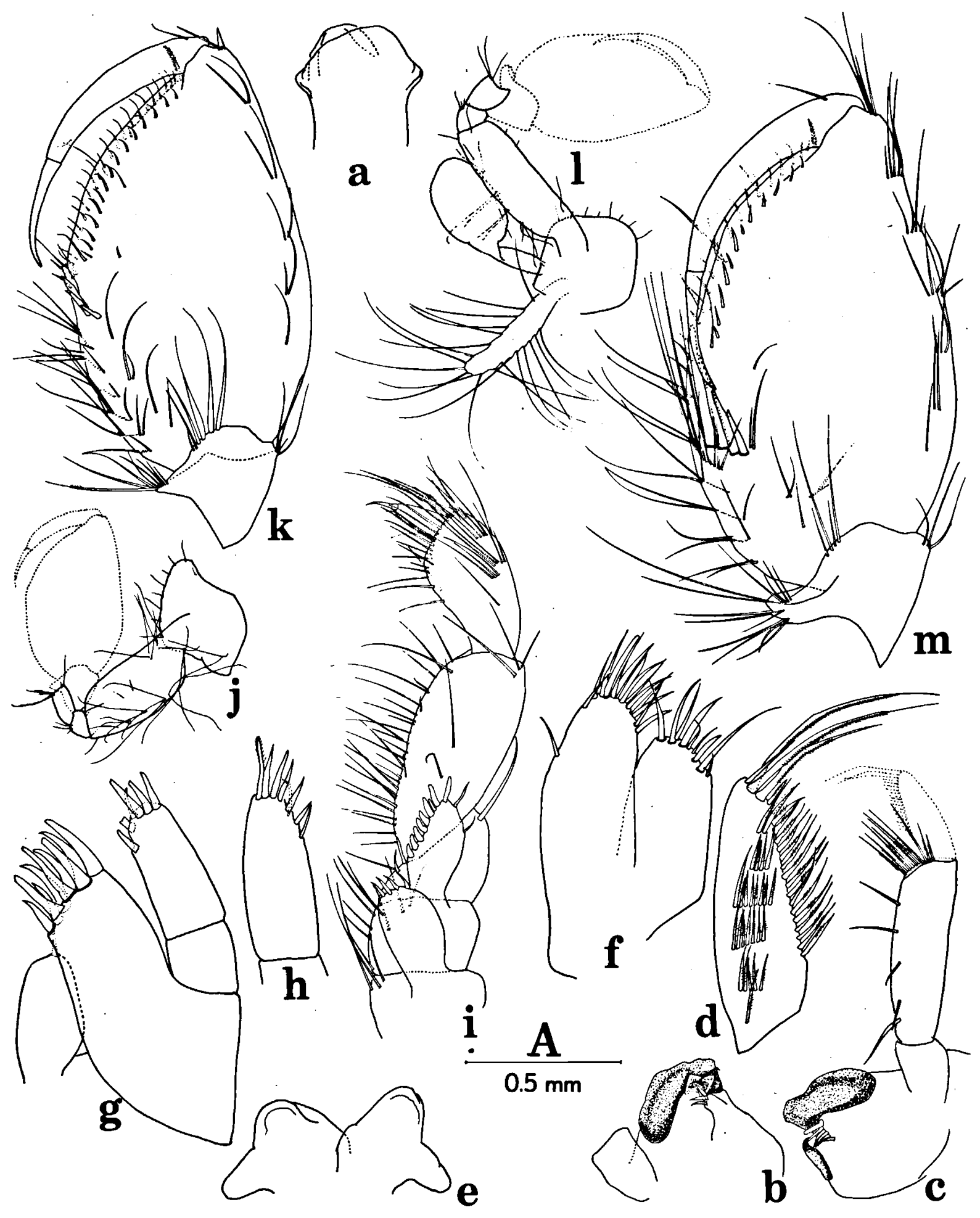

Fig. 3. Sensonator valentiensis $\mathrm{n}$. sp. (a-h, and j-m, \&, $10.5 \mathrm{~mm}$, from Guardamar; i, $९, 12.5 \mathrm{~mm}$, from San Barnardo): a, upper lip (scale A); b, left mandible (A); c, right mandible (A); d, third palp segment of right mandible (B); e, lower lip (A); f, second maxilla (A); g, first maxilla, right side (B); h, terminal palp segment of first maxilla, left side (B); i, maxilliped (A); j, first gnathopod (A); $k$, propodus of first gnathopod (A); 1 , second gnathopod (A); m, propodus of second gnathopod $(A)$. 


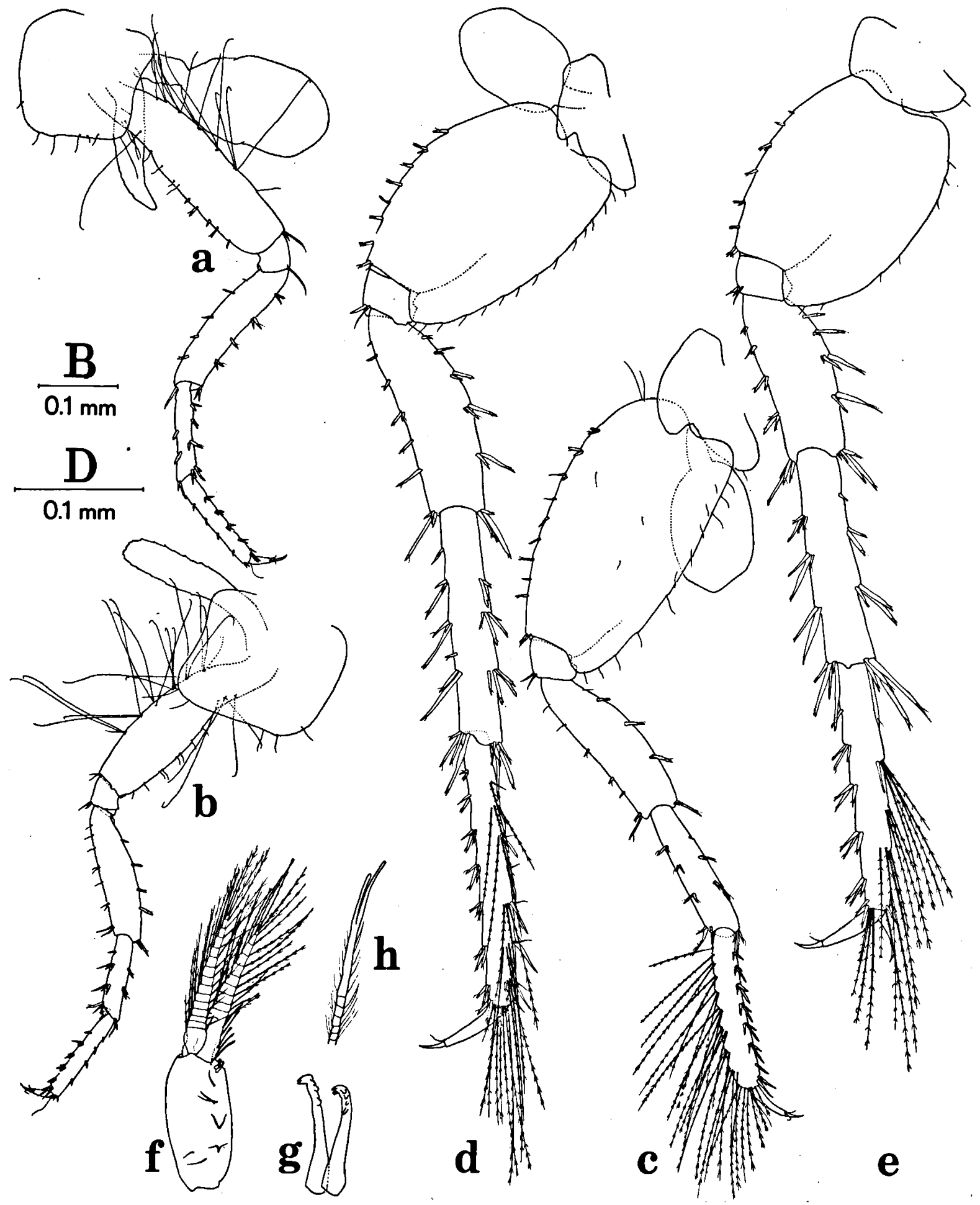

Fig. 4. Sensonator valentiensis n. sp. (a-e, \&, $12.5 \mathrm{~mm}$, from San Bernardo; $\mathrm{f}-\mathrm{h}$, \&, $10.5 \mathrm{~mm}$, from Guardamar): a, third pereiopod (scale C); b, fourth pereiopod (C); c, fifth pereiopod (C); d, sixth pereiopod (C); e, seventh pereiopod (C); $f$, third pleopod (G); $g$, retinacula of third pleopod (D); h, tip of clothespeg spine of third pleopod (D). 


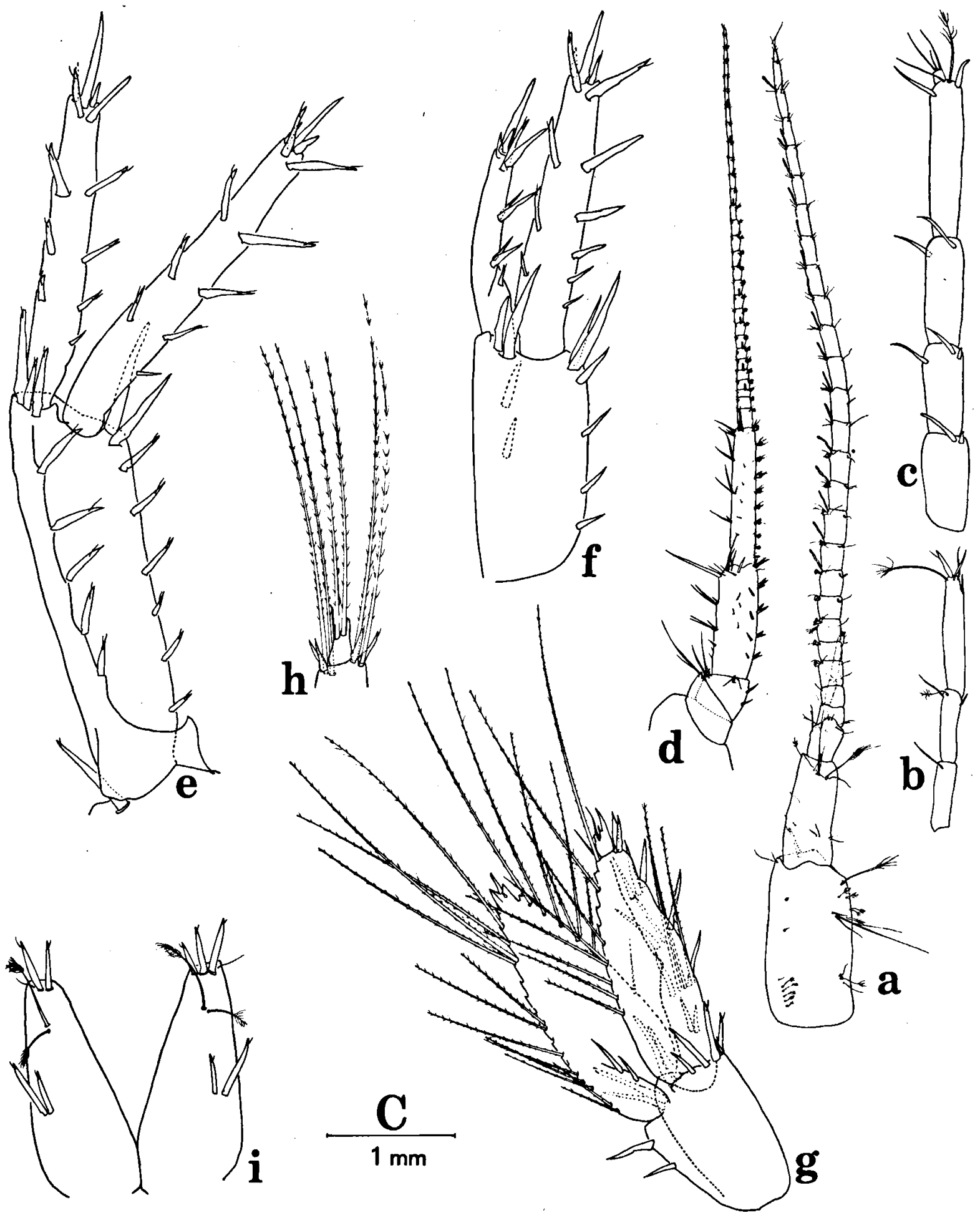

Fig. 5. Sensonator valentiensis $\mathrm{n}$. sp. (a-b,,, $7.5 \mathrm{~mm}$, and $\mathrm{c}$ and $\mathrm{h}, \uparrow, 12.5 \mathrm{~mm}$, both from San Bernardo; $\mathrm{d}-\mathrm{g}$ and $\mathrm{i}$,, $10.5 \mathrm{~mm}$, from Guardamar): a, first antenna (scale A); b, 3-segmented accessory flagellum (B); c, 5-segmented accessory flagellum (B); d, second antenna (C); e, first uropod (C); f, second uropod (C); $g$, third uropod $(C)$; $h$, terminal segment of exopodite of third uropod (A); $i$, telson (A). 
overhanging, armature of margins comparable to P5. Basis of P7 (fig. 4e) of rather globular shape, posterodistal angle strongly overhanging, anteriorly armed with 6 groups of spines and posteriorly with 12 setules.

Epimeral plates (fig. 2): posterodistal corners rectangular with small tooth, posterior margins with small setae; anterior part of ventral margin of plates 2 and 3 with 1 or 2 groups of spines, respectively.

Pleopods (fig. 4f) slightly decreasing in length in posterior direction; peduncle distomedially with two retinacula (fig. $4 \mathrm{~g}$ ); rami of equal length armed with many long plumose setae; basal segments of the endopodites with 5 or 6 clothespeg spines (fig. 4h) on inner margin.

First and second urosomites (fig. 2) with few dorsal and dorsolateral spines; ventral surface of urosomite 1, near implantation of first uropod, with large spine (fig. 5e). Third urosomite (fig. 2) with some dorsal and ventrodistal spines.

First uropodal peduncle (fig. 5e) with many dorsal and medial spines, basoventral spine lacking; both rami with two rows of spines, subequal in length, not exceeding length of peduncle.

Second uropod (fig. 5f) with dorsal and medial spines on peduncle; rami armed with spine rows on both margins, exopodite much smaller than endopodite.

Third uropodal peduncle (fig. $5 \mathrm{~g}$ ) with medial spines and a group of long distolateral spines; rami of equal length, subfoliaceous and bearing many long plumose setae on margins; endopodite with single apical and subapical spines, and few lateral spines; exopodite 2segmented, lateral margin with long spines and some shorter apical spines, terminal segment (figs. $5 \mathrm{~g}, \mathrm{~h}$ ) very small, with apical process.

Telson halves (fig. 5i) longer than wide, each half with 2-3 apical spines and a sensory setule, laterally one pair of sensory setules, and 2 spines.

No secondary sexual differences observed.

Remarks on microstructures. - Body somites of Sensonator with groups of microtrich sensilla (fig. 6a), which are arranged on anterior pereion segments in dorsal and lateral rows, and on posterior segments only in a lateral row; most likely they belong to the sideline organ as described by Platvoet (1985). Dorsal groups are composed of 3-4, lateral groups of 2-4 microtrich sensilla, the length of the sensillum is $4-5 \mu \mathrm{m}$.

The cuticular surface shows subparallel grooves (fig. 6b) which do not depass the boundaries of each epidermal cell.

Calceoli of a rather simple configuration (figs. 6c-e), proximal element consisting of a rather wide crescentic plate, closely abutting on its inner margin to distal element. Latter composed of two small plates which join together. Bulla (fig. 6d) at proximal end of receptacle well developed.

\section{RELATIONSHIPS}

The affinities of the genus Sensonator within the Amphipoda, especially the Gammaridea, are very difficult to trace. The new taxon is very distinct from such widespread stygobiont groups as the niphargids and crangonyctids, and it is closer to the gammarids. Compared with the diagnosis of the Gammaridae given by Lincoln (1979), Sensonator agrees in the following characteristics: presence of dorsal urosome spines, anterolobate coxae 5 and 6 , deeply excavated inferior antennal sinus, multiarticulate accessory flagellum, lower lip without inner lobes, robust subchelate gnathopods, second gnathopod slightly larger than first, broad basis of pereiopods 5 to 7 , setose third uropod with 2segmented exopodite, and cleft telson.

However, classification of Sensonator within the Gammaridae is contradicted because in that family males are larger than females (probably the reverse in Sensonator), gnathopods are unequal and sexually dimorphic, mouthparts are unmodified with 11 spines on inner plate of maxilla 1 , facially setose inner plate of maxilla 2 and well developed inner and outer plates of maxilliped. With exclusion of the mouthparts, the diagnosis of Sensonator concurs with that of the superfamily Gammaroidea given by Bousfield (1982). 


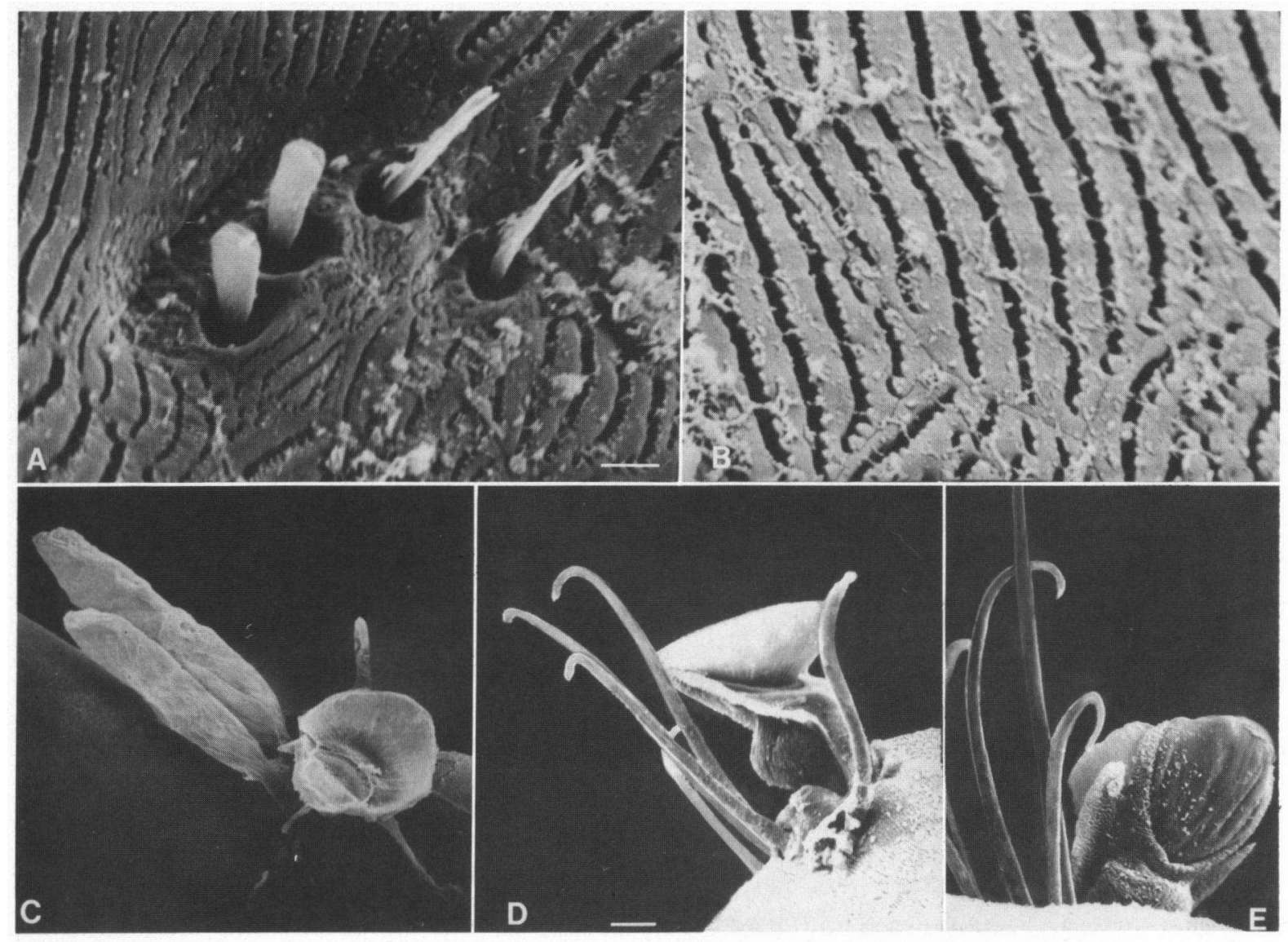

Fig. 6. Sensonator valentiensis n. sp.: A, group of microtrich sensilla (scale bar $2.71 \mu \mathrm{m}$ ); B, cuticular surface of pereion segment 4 (scale bar on A $1.62 \mu \mathrm{m}$ ); C, calceoli and aesthetascs on flagellum segment 5 of antenna $1, \sigma^{\circ}$ (scale bar on A $7.75 \mu \mathrm{m}$ ); D and E, calceoli on last peduncular segment of antenna 2, \& (scale bar on D 6.90 and $6.25 \mu \mathrm{m}$, respectively).

According to the classification of calceoli proposed by Lincoln Hurley (1981), the microstructure of Sensonator calceoli also agrees with that of the gammarids. However, the distribution of the calceoli of Sensonator, along the antennae and between the sexes, has neither been found in the Gammaridae, nor in the superfamily Gammaroidea (Bousfield, in press).

An important group of subterranean gammarids are those genera arranged around the genus Hadzia. The nomenclature of this group is confusing: Stock (1977) called them the hadziid Amphipoda, but Bousfield (1977) used the family name Hadziidae. This group is considered to be a melitid facies which invaded continental groundwaters (Barnard \& Barnard, 1983; Stock, pers. comm.). Melitidae are difficult to separate from the Gammaridae because of existing intermediate taxa. But the affinity of Sensonator with the Melitidae, and therefore with the hadziids, is looser than with the Gammaridae. In the Melitidae no calceolate species are known, and some other important dissimilarities from Sensonator are found in the peduncle of the first antenna with elongated second segment, and the strongly expressed sexual dimorphism in the antennae and gnathopods.

In some characters the appendages of Sensonator remind us of the exclusive marine Liljeborgioidea. Several characteristics of Sen- 
sonator point to a relationship with the Pardaliscidae (or Pardaliscoidea), particularly with the stygobiont genus Spelaeonicippe Stock \& Vermeulen, 1982. Above all, these similarities are found in the mouthparts: mandible with reduced molar and nontriturative incisor, lower lip without inner lobes and small maxillipedal lobes. Furthermore, the first antenna being shorter than the second, coxae 1 to 4 subquadrate, pereiopods 5 to 7 with variable expanded bases, rami of first uropod unequal, third uropod natatory, telson long and deeply cleft, and the lack of sexual secondary differences, are shared by both taxa.

The resemblances in the mouthparts can be considered as synapomorphies. However, they are for an important part based on reductions, hence the danger of convergencies is not imaginary, resulting in less convincing affinities between Sensonator and the Pardaliscidae.

Besides the similarities to the Gammaroidea and Pardaliscoidea, Sensonator resembles the Bogidiellidae in some characters: small maxillipedal lobes, small inner lobe of the first maxilla, and small coxae. But in many other features, such as the mandible, pleopods, third uropod, and telson, Sensonator differs markedly from the Bogidiellidae.

The genus Artesia Holsinger, in Holsinger \& Longley (1980), for which originally a new family, Artesidae, was erected, but classified in the Bogidiellidae by Stock (1981), resembles Sensonator more strongly than the other genera of this family. Artesia has biramous and plurisegmented pleopods (although less developed than in Sensonator), uropod 3 with setose rami (although not subfoliaceous and with 1-segmented exopodite), and deeply emarginated telson (although not totally cleft). Besides, Artesia has antenna 1 longer than antenna 2, a 1-segmented accessory flagellum, scantily armed mandible palp segment 3 , and no expanded bases of pereiopods 5 to 7 . Therefore even this genus cannot be placed close to Sensonator.

In the view of Bousfield (in press), calceoli are most strongly developed in primitive, pelagic and carnivorous amphipods, and are lost with increasing specialization and "derivation" of the more benthic members. First they disappear from antenna 1 , and then from antenna 2, eliminated first from the peduncle and persisting last on the flagellum. Once lost within a phyletic lineage, calceoli do not appear again in the descendants of that lineage. The distribution of calceoli on both antennae and in both sexes is a remarkable feature of Sensonator, as stygobiont amphipods rarely retain calceoli.

Other amphipod taxa with calceoli distributed on both antennae in males and females are Micropus, Psammonyx, several families of the Eusiroidea and Exoediceroides, but from these taxa only the eusirid groups possess calceoli also on the last peduncular segment of antenna 2. The microstructure of the eusirid calceoli is quite different from the gammarid type.

About the phyletic position of the new genus we can conclude with our present knowledge that Sensonator most probably is a relict of an early free-swimming Gammaroidea- and/or Pardaliscoidea-like ancestral group. However, its origin remains enigmatic.

One might argue creation of a new family for Sensonator, which can be placed in the Gammaroidea, the diagnosis of which undoubtedly overlaps that of the Gammaridae and Pardaliscidae. But I hesitate doing this, because of the many controversies which exist at the moment about the systematics of many higher amphipod groups, especially those in the Gammaridae cluster. Till now there is no measure of agreement about definitions of families and superfamilies, and I prefer therefore to be very careful in not creating more confusion.

\section{ECOLOGICAL NOTES}

\section{Field observations}

The new species described in this paper has been found in different biotopes, all situated in a limited area within $30 \mathrm{~km}$ from the seashore (fig. 1). The waters in which this species lives can be classified as fresh, maximal chlorinity 
measured $142 \mathrm{mg} / \mathrm{l}$ at the river Turia $(27 \mathrm{~km}$ from the coast).

With exception of Cueva Blanca, all localities of $S$. valentiensis are related to alluvia. The bedding plane of the river Turia between Villamarchante and Liria consists of Quaternary sediments, which are deposited on a thin layer of underlying Upper Miocene lacustrine sands and clays. The Miocene in the area is directly superimposed on the Late Cretaceous, since Paleogene sediments are lacking, while the large transgression during the Burdigalian (Lower Miocene) did not reach the area**. The wells at Gandia and Corbera de Alcira are fed by aquifers in Quaternary sediments ${ }^{* *}$. The mountains in the area between Alcira and Gandia are composed of Jurassic but principally Cretaceous rocks, with large beds of limestones and dolomites***. In one of these mountains, the Sierra de Corbera, Cueva Blanca is situated.

Not at any of the localities $S$. valentiensis occurred in large densities. In the area which is inhabited by $S$. valentiensis, so far we know at the moment roughly corresponding with the $\mathrm{YJ}$ UTM square, a total number of 26 wells, 2 caves with access to the water table and 1 hyporheic station in the river Turia (another station in this river is located just outside this UTM square) have been investigated (Notenboom \& Meijers, 1985). Only two wells, one of the caves and the hyporheic habitat yielded these animals, this as an illustration of its relative rareness, especially in the wells of the area.

In the hyporheic habitat of the river Turia (fig. 7A), S. valentiensis was only a very small part, both in quantitative and in qualitative respect, of the total stygobiont fauna. In the phreatic lake of Cueva Blanca only three specimens of $S$. valentiensis were spotted and

* Consulted is sheet 695 (Liria), 1958, 1:50.000 of the geological map of Spain (Institute Geologico y Minero de España).

*** Consulted is the geological map of Spain 1:50.000, sheets 722 (Valencia), 1972; 747 (Sueca), 1979; and 796 (Gandia), 1973; and the geological map of the peninsula, 1:1.000.000 (Instituto Geologico y Minero de España). captured, although much time was spent at this site. Most of the specimens studied were captured in the well of San Bernardo (fig. 7B), about $500 \mathrm{~m}$ in straight line from Cueva Blanca.

In the wells and the cave, baited traps were suspended for some 24 hours. According to the recommendations of Boutin \& Boulanouar (1983), different types of traps were used, the classical balance and the bow net, both baited with beef. The bow nets in the wells did not yield any fauna, the balances only some gastropods. In the cave lake the balance did not attract animals, while two bow nets contained many Typhlocirolana (Isopoda). Curiously, not any of these large isopods has been observed creeping or swimming in the lake, and not any $S$. valentiensis has been attracted by the traps.

In July 1985, specimens of $S$. valentiensis captured in the well of San Bernardo have been observed for a while in a large vial. Cannibalism of this species could be observed. A small specimen, not very vivacious but still moving was grasped by a large, about $12 \mathrm{~mm}$ long, female. The small animal was consumed for a fourth part in about 15 minutes.

In the cave lake the animals were creeping over the muddy bottom, but when the water was disturbed they began to swim, very fast and sensitive to movements in the water. In a jar the animals also could be seen swimming with extended and rapidly moving third uropods, while simultaneously the antennae were straightly stretched out, the first antenna forward and the second slanting downward.

\section{Discussion}

Considering the morphology of Sensonator in relation to its life in hypogean habitats, two features are noteworthy above all: the many calceoli-packed on the antennae and the natatory third uropod. Few stygobiont amphipods retain calceoli. These antennal organs seem to be of little advantage in hypogean life. About the function of these organs no complete clarity seems to exist. Lincoln \&urley (1981) discussed this problem in detail. They 


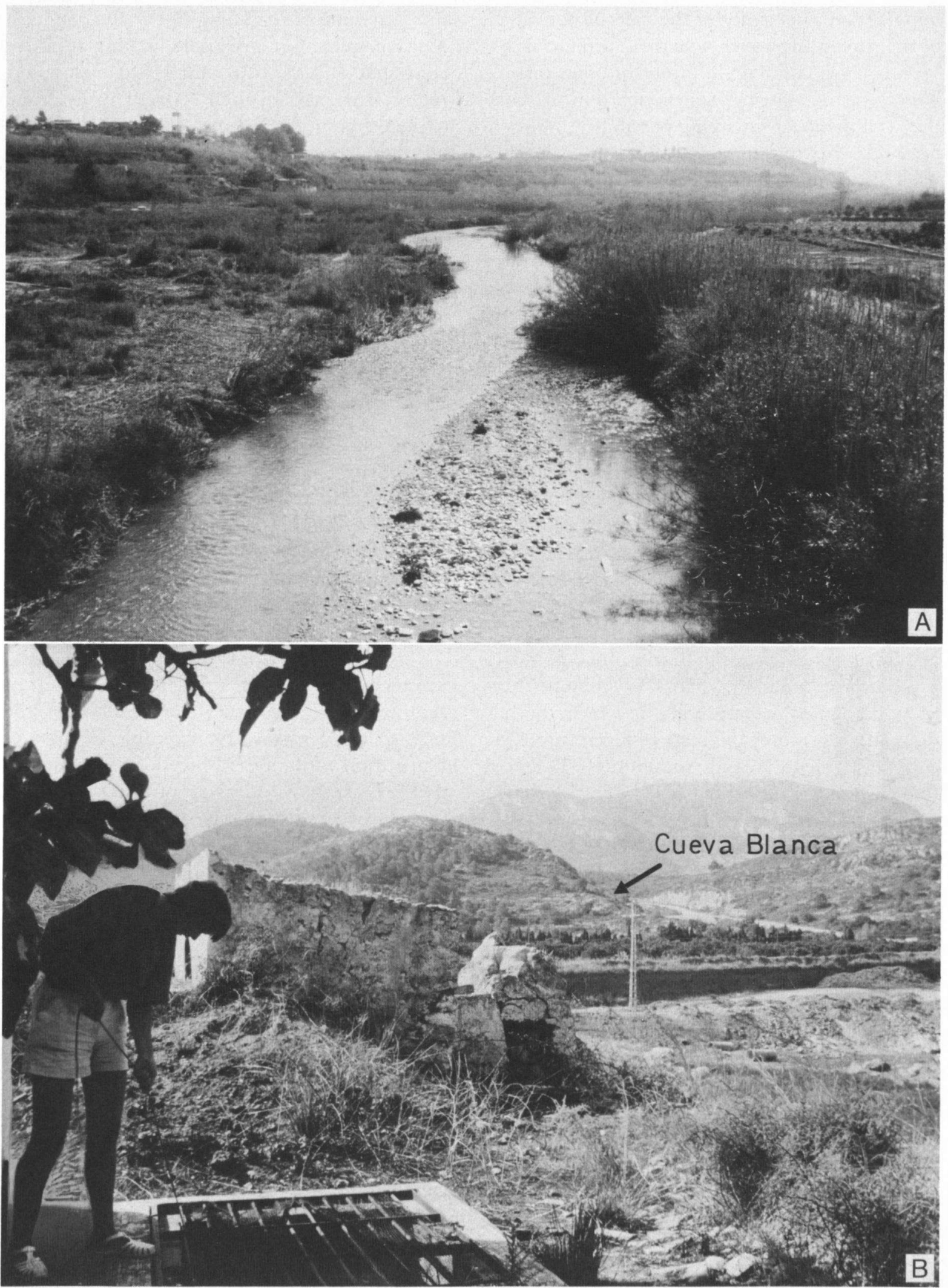

Fig. 7. A, View of the river Turia between Villamarchante and Liria. B, The sampling of the well of San Bernardo, with in the background the hill in which Cueva Blanca is situated. 
hypothesize a sensivity of the calceoli to waterborne pressure waves whether produced by sound waves, animal vibrations or other disturbances in the water. Their conclusion or what they call the most satisfying possibility, is based on both the microstructure of the calceolus itself, and the arrangements of the calceoli along the antennal axis. Our observations about the position of the antennae during swimming, the sensitivity of Sensonator to disturbances of the water, and the grasping of prey, are in agreement with the sonar theory of Lincoln \&urley. According to these ideas the system of calceoli is only an advantage when the animal lives in habitats in which pressure waves can move forward, consequently in larger water bodies. It may be for this reason that the majority of stygobiont amphipods, living in small crevices or interstitia, do not have calceoli; and it suggests that Sensonator above all is an inhabitant of large waterfilled fissures, in which the calceoli are used to identify the approach of other animals, either of the same species or prey.

The morphology of the third uropod points to a natatory function. Most stygobiont amphipods have third uropods in which the endopodite is more or less reduced and the exopodite slender and sometimes elongated (e.g. some Niphargus and Pseudoniphargus species), in others both endopodite and exopodite are strongly reduced (e.g. Metacrangonyx, Crangonyx, and Stygobromus species). The natatory third uropod of Sensonator does not point to an interstitial mode of life, neither does the shape of the body. Although the animals were found in a hyporheic habitat, it also has been observed that they are good swimmers. It has to be noted that the specimens found in the hyporheic habitat were very small (up to 4.5 $\mathrm{mm})$.

Based on the morphology and the limited field observations, some tentative conclusions about the biology of $S$. valentiensis can be drawn. Firstly, although they have been found in interstitial habitats, and wells related to nonkarstic aquifers, their principal biotope is supposed to be the system of large fissures in the saturated zone of the karst. Secondly, they are no scavengers, but predators, taking into account that also detritus, microorganisms and fungi can be part of their food. Thirdly, they are good swimmers but also substrate dwellers, and they can move through (macro)porous substrates. Finally, they are sensitive to movements of other animals and disturbances in the water.

\section{EVOLUTIONARY SCENARIO}

Two components, as already noticed previously, are important in proposing a reconstruction of the evolutionary history of Sensonator, viz., the assumed free-swimming marine ancestor and the supposition that the most favorable biotope of Sensonator is the saturated zone of the karst. In the scenario we attribute an important role to the littoral karst. The ancestor of Sensonator penetrated first from the marine environment into marine caves or karst fissures and marginal caves, eventually it colonized the more inland anchialine habitats. The impulse behind this dispersal can be a vacant niche in the karst, or the marine environment which became less favorable for the ancestor of Sensonator, for example because of competition with modern invaders or ecological stress. During withdrawal of the sea, karst biotopes became successively isolated from the marine biotopes, while at the same time the ancestor of Sensonator adapted to brackish or limnic conditions. In a later stage these limnic populations penetrated also into macroporous alluvial sediments which drain the phreatic karst waters. However, from the restricted area in which Sensonator lives it can be concluded that suitable dispersal routes through macroporous interstitia or large fissures are limited, or that the dispersal potential of Sensonator is low. The marine ancestor of Sensonator is unknown, and it might have gone extinct during periods of ecological stress, such as the salinity crisis in the Mediterranean basin during the Late Miocene (Messinian). Much has been published in the geological literature about this event; see for example Hsü et al., 1977, and Cita, 1982. 
Most likely, penetration of the karst by Sensonator took place at the time that the karstified mountain ridges of S.E. Valencia were situated in the littoral zone during the last transgression. These mountains are of Lower and Upper Cretaceous, and Jurassic age, and the coastal plain and many of the valleys in connection with this plain are composed of Quaternary alluvia. Only small parts of the area are covered by Tertiary sediments of Miocene (pre-Messinian) age. In general the marine Tertiary is poorly represented in the area (see footnote ${ }^{* * *}$ ).

The outline palaeogeographical maps of Iberia given by Azema \& Fourcade (in Aubouin et al., 1981) indicate that the distribution area of Sensonator is influenced by Late Cretaceous and Late Miocene seas. However, very little has been published about the detailed palaeogeography of the area, so it is difficult to confirm the information of Azema \& Fourcade on the geology of the area concerned. No information could be traced on the geological maps about age and character of the rocks underlying the Quaternary alluvia, thus it is difficult to get proof about the influence of marine Miocene transgressions in the area. However, it can not be excluded that Cretaceous and Jurassic outcrops have been part of the littoral during Tertiary, especially Miocene, times.

Champetier (1967) gives an indication about the palaeogeography of the Sierra de Corbera (in which Cueva Blanca is located) during the Upper Cretaceous, stating that at that time it was situated very close to the coastline.

It has to be stressed that in pre-Miocene times the Jurassic and Cretaceous structures in the area did not end near the actual coastline, but continued. The opening of the gulf of Valencia, leading to the formation of the actual coastline took place during the Miocene. Our area was still influenced by tectorogenesis during Eocene till Lower Miocene times. These movements were related with the evolution of the Iberides (Canerot, 1985). Karstification, geologically a young phenomenon, just started after the raising of the mountain ridges in the area.

The area around Villamarchante and Liria, in which the hyporheic station at the river Turia is located, is not included in this discussion to avoid confusion, because it is remote from the geologically rather coherent area between Alcira and Gandia, in which the other localities are situated.

In conclusion, I believe that the ancestor of Sensonator was part of a pre-Messinian Mediterranean (= Tethys) fauna. It colonized caves and fissures of the littoral karst connected with the sea, most likely during the Miocene, but it cannot be excluded that this occurred during the Late Cretaceous. Indeed, many questions remain unsolved about the palaeogeography of S.E. Valencia.

The proposed evolutionary scenario of Sensonator resembles in some aspects the regression evolution model, although the latter was developed for benthic groups with low dispersal properties (Stock, $1977 \& 1980$ ). The hypothetical scenario of Sensonator begins with a freeswimming ancestor which more or less actively invaded biotopes in the littoral karst, while in a later stage dispersal into macroporous alluvia is assumed. The regression model is entirely a vicariant model, and the Sensonator scenario has a vicariant component, viz. the withdrawal of the epicontinental sea by which the continental populations became isolated from the marine ancestral populations. But, the scenario also has dispersal components, viz. occupation of the karst from the marine environment, and penetration from the karst into macroporous alluvia.

\section{ACKNOWLEDGMENTS}

I am indebted to Prof. Dr. J. H. Stock for reviewing the successive drafts of the manuscript, and to Dr. E. L. Bousfield and Prof. Dr. S. Ruffo for communications about the phyletic placement of the new genus. Dirk Platvoet is thanked for assistance with the SEM survey of the animal.

The investigations were supported by the Foundation for Fundamental Biological Research (BION), which is subsidized by the Netherlands Organisation for the Advancement of Pure Research (Z.W.O.).

\section{REFERENCES}

Aubouin, J., R. Brousse \& J.-P. Lehman, 1981. Tratado de geología: 1-607 (Omega S. A., Barcelona).

Barnard, J. L. \& C. M. Barnard, 1983. Freshwater Amphipoda of the world, I. Evolutionary patterns, II. 
Handbook and bibliography: 1-830 (Hayfield Associates, Mt. Vernon, Virginia).

Bousfield, E. L., 1977. A new look at the systematics of gammaroidean amphipods of the world. Crustaceana, Suppl. 4: 282-316.

- -, 1982. Amphipoda. In: P. PArker ed., Synopsis and classification of living organisms: 254-293 (McGrawHill, New York).

-, , in press. Ordered character states as a basic for phyletic classification within the Amphipoda. Proc. VIth int. Colloquium on Amphipoda, Ambleteuse, 1985. Crustaceana Suppl. 12.

Boutin, C. M. Boulanouar, 1983. Méthodes de capture de la fauna stygobie: Expérimentation de différents types de piège appatés dans les puits de Marrakech. Bull. Fac. Sci. Marrakech, (Sci. Vie) 2: 5-21.

Canerot, J., 1985. La chaîne alpine des Ibérides (Espagne): un exemple d'évolution sédimentaire et tectonique intraplaque. Archs. Sci. Genève, 38 (1): 37-62.

Champetier, Y., 1967. Le Crétacé Supérieur de massifs de Corbera (prov. Valencia, Espagne), présence de faciès saumâtres et d'accumulations détritiques. C. r. hebd. Séanc. Acad. Sci., Paris, 265: 396-399.

CrtA, M. B., 1982. The Messinian salinity crisis in the Mediterranean: a review. In: H. BERCKHEMER \& $K$. J. Hsü eds., Alpine-Mediterranean geodynamics, Geodynamic Series, 7: 113-140 (American Geophysical Union, Washington D.C.).

Holsinger, J. R. * G. Longley, 1980. The subterranean amphipod crustacean fauna of an artesian well in Texas. Smithson. Contr. Zool., 308: i-iii, 1-62.

Hsü, K. J., L. Montadert, D. Bernoull, M. B. Cita, A. Erickson, R. E. Garrison, R. B. Kidd, F.
Mèlierés, C. Müller \& R. Wright, 1977. History of the Mediterranean salinity crisis. Nature, Lond., 267 (5610): 399-403.

Lincoln, R. J., 1979. British marine Amphipoda: Gammaridae: i-vi, 1-658 (British Museum Natural History, London).

Lincoln, R. J. \&. E. Hurley, 1981. The calceolus, a sensory structure of gammaridean amphipods (Amphipoda: Gammaridae). Bull. br. Mus. nat. Hist., (Zool.) 40 (4): 103-116.

Notenboom, J. I. Meijers, 1985. Investigaciones sobre la fauna de las aguas subterráneas de España: Lista de estaciones e primeros resultados. Verslagen en technische Gegevens Inst. taxon. Zoöl. Amsterdam, 42: $1-85$.

Platvoet, D., 1985. Side-line organ in gammarids (Crustacea, Amphipoda). Beaufortia, 35 (7): 129-133.

Stock, J. H., 1977. The taxonomy and zoogeography of the hadziid Amphipoda, with emphasis on the West Indian taxa. Stud. Fauna Curaçao, 55 (177): 1-130.

-, 1980 . Regression model evolution as exemplified by the genus Pseudoniphargus (Amphipoda). Bijdr. Dierk., 50 (1): 105-144.

- , 1981. Amsterdam Expeditions to the West Indian Islands, Report 14. The taxonomy and zoogeography of the family Bogidiellidae (Crustacea, Amphipoda), with emphasis on the West Indian taxa. Bijdr. Dierk., 51 (2): 345-374.

Stock, J. H. \&. J. Vermeulen, 1982. Amsterdam Expeditions to the West Indian Islands, Report 16. A representative of the mainly abyssal family Pardaliscidae (Crustacea, Amphipoda) in cave waters of the Caicos Islands. Bijdr. Dierk., 52 (1): 3-12. 